\title{
Evaluation of Chickpea (Cicer arietinum L.) Germplasm for the Resistance to Gram Pod Borer, Helicoverpa armigera (Hübner) in Tarai Region of Uttarakhand
}

\author{
S. D. Divija* and Meena Agnihotri \\ Department of Entomology, College of Agriculture, G.B. Pant University of Agriculture \& \\ Technology, Pantnagar, Uttarakhand, India \\ *Corresponding author
}

\section{Ke yw o r ds \\ Chickpea \\ Cicer arietinum, \\ Gram Pod Borer, \\ Helicoverpa \\ armigera \\ Article Info \\ Accepted: \\ 17 August 2020 \\ Available Online: \\ 10 September 2020}

\section{A B S T R A C T}

Screening of chickpea germplasm was carried out at Norman E. Borlaug Crop Research Centre, Pantnagar during winter season of 2017-18, with the objective of identifying the source of resistance to $H$. armigera. Observation recorded over a period of six weeks revealed that, the minimum mean egg $(0.28$ eggs $/ 5$ plants $)$ and larval population ( 0.5 larvae/5 plants) were recorded on ICC 372351. Minimum pod damage of 5.56 per cent was recorded on ICC 372351, whereas the maximum grain yield of $1071.58 \mathrm{~kg} / \mathrm{ha}$ was recorded on ICC3404. The germplasm viz. ICC4484 (3), ICC4260 (3), ICC244624 (3), ICC372351 (3) and ICC3089 (3) were rated as least susceptible based on pest susceptible rating.

\section{Introduction}

Chickpea, Cicer arietinum is one of the most important rabi pulse grown all over the world. India is the single largest producer of chickpea accounting for 65 per cent of the total production. In India Chickpea was cultivated in an area of 9.01 million hectares with a production of 7.58 million tonnes accounting for 34.3 per cent and 45.6 per cent of total pulse area and production (FAOSTAT, 2017). The production and productivity of chickpea has been drastically reduced by the biotic and abiotic stresses. Nearly sixty insect pest feed on chickpea, of which Gram Pod borer, Helicoverpa armigera (Hübner) is a pest of great economic importance in chickpea, and it is the major limiting factor in chickpea cultivation. In severe cases it causes about 75 to 90 per cent losses in seed yield (Sarwar, 2013), despite the application of costly insecticides. This pest alone reported to cause losses over Rs. 35000 million annually in India (Kumar, 2003). It has also developed high levels of resistance to several insecticides and in addition to the huge direct economic losses, deleterious effects of pesticides remain in the environment. Therefore, development of a cost effective and an environmentally friendly 
approach like improvement of cultivars resistant to $H$. armigera is necessary. The resistant cultivars reduce yield losses due to insect pests, particularly under subsistence farming conditions in the developing countries. Therefore, the present research was undertaken to screen and identify the tolerant chickpea germplasm to $H$. armigera.

\section{Materials and Methods}

Eleven germplasm along with resistant checks (GL25016 and ICCL86111), susceptible check (ICC3137) and local check (PG186) were screened at Norman E. Borlaug crop research centre (NEB-CRC), G.B.P.U.A \& T, Pantnagar, under natural field conditions during Rabi season of 2017-18. The germplasm were grown in plot of $2 \mathrm{~m} \times 3 \mathrm{~m}$ with spacing of $10 \times 30 \mathrm{~cm}$, in randomized block design with three replications. The germplasm were assessed in terms of egg and larval population per five plants at weekly interval from the date of first larval appearance till the maturity of the crop. Per cent pod damage from five randomly selected plants of each replicated plot and the final grain yield was also assessed at harvest stage. The pest susceptibility rating was calculated and graded as per the method given by Lateef and Sachan (1990).

Per cent pod damage $=$

Number of damaged pods

Total number of pods $\times 100$

Tukey's HSD test was used to compare differences among treatment means $(\mathrm{P}<0.05)$ using statistical package for social sciences (SPSS) Software, version 16.

\section{Results and Discussion}

The results pertaining to the mean egg and larval population per five plants, per cent pod damage, pest susceptibility ratings (PSR) and yield $(\mathrm{kg} / \mathrm{ha})$ of various germplasm screened for their reaction to $H$. armigera and the susceptibility ratings based on pest susceptibility ratios obtained from pod damage with respect to PG186 are presented below.

\section{Mean egg population per five plants}

The data on the number of eggs of $H$. armigera per five plants was recorded from the time of build-up of the insect population $\left(8^{\text {th }} \mathrm{S}\right.$.W. $)$ to the maturity of the crop $\left(13^{\text {th }}\right.$ S.W. $)$ are presented in the Table 1 . During the $8^{\text {th }}$ S.W. maximum numbers of eggs (1.33 eggs/5 plants) in germplasm ICC2767 and no eggs in germplasm ICC4484, ICC4260, ICC3552, ICC372351, ICC3404 and ICC3089 were observed as against the check's PG 186 (0.67 eggs/5 plants), ICCL86111 (0.33 eggs/5 plants) and ICC3137 (0.33 /5 plants). A nonsignificant difference was observed between germplasm and their checks. Egg population during $9^{\text {th }} \mathrm{S}$.W. varied non-significantly from nil on ICC3552 and ICC372351 to the highest of $1.67 \mathrm{eggs} / 5$ plants on ICC2767 as compared to 1.33 eggs/5 plants on check PG 186 . A nonsignificant difference in egg population among the germplasm and their checks were observed during $10^{\text {th }} \mathrm{S}$.W. however, it ranged from 0.0 to 2.00 eggs/per 5 plants on germplasm as against 0.67 to $1.67 \mathrm{eggs} / 5$ plants on check varieties. During the $11^{\text {th }} \mathrm{S}$.W. the population varied non-significantly from 1.00 to $2.67 \mathrm{eggs}$ per 5 plants on germplasm as against 0.33 to 1.67 eggs per 5 plants on checks. Egg population during $12^{\text {th }} \mathrm{S} . \mathrm{W}$. varied nonsignificantly from a minimum of $0.33 \mathrm{eggs} / 5$ plants on ICC6263, ICC372351 and ICC3404 to maximum of 3 eggs/5 plants on ICC2767 as against 0.67 to 2.33 eggs/5 plants on check varieties. There was no egg population were observed during $13^{\text {th }} \mathrm{S}$.W. When overall mean egg population of $H$. armigera was considered there were non-significant differences among the test germplasm. 
Table.1 Screening chickpea germplasm against eggs and larvae of H. armigera during 2017-18

\begin{tabular}{|c|c|c|c|c|c|c|c|c|c|c|c|c|c|c|}
\hline \multirow[t]{2}{*}{ Germplasm } & \multicolumn{7}{|c|}{ Number of eggs of $H$. armigera per 5 plants } & \multicolumn{7}{|c|}{ Number of larva of $\boldsymbol{H}$. armigera per 5 plants } \\
\hline & $8^{\text {th }}$ S.W. & $\begin{array}{c}9^{\text {th }} \\
\text { S.W. }\end{array}$ & $\begin{array}{c}10^{\text {th }} \\
\text { S.W. }\end{array}$ & $\begin{array}{l}11^{\text {th }} \\
\text { S.W. }\end{array}$ & $\begin{array}{c}12^{\text {th }} \\
\text { S.W. }\end{array}$ & $\begin{array}{c}13^{\text {th }} \\
\text { S.W. }\end{array}$ & $\begin{array}{c}\text { Pooled } \\
\text { mean }\end{array}$ & $\begin{array}{c}8^{\text {th }} \\
\text { S.W. }\end{array}$ & $9^{\text {th }}$ S.W. & $\begin{array}{c}10^{\text {th }} \\
\text { S.W. }\end{array}$ & $\begin{array}{c}11^{\text {th }} \\
\text { S.W. }\end{array}$ & $\begin{array}{c}12^{\text {th }} \\
\text { S.W. }\end{array}$ & $\begin{array}{c}13^{\text {th }} \\
\text { S.W. }\end{array}$ & $\begin{array}{c}\text { Pooled } \\
\text { mean }\end{array}$ \\
\hline ICC4484 & $0^{\mathrm{a}}$ & $0.67^{\mathrm{ab}}$ & $0.33^{\mathrm{ab}}$ & $1^{\mathrm{ab}}$ & $1.333^{\mathrm{abc}}$ & 0 & $0.44^{\mathrm{ab}}$ & $0.67^{\mathrm{a}}$ & $0^{\mathrm{a}}$ & $1.33^{\mathrm{abc}}$ & $1^{\mathrm{abc}}$ & $2.67^{\mathrm{abcd}}$ & $0.67^{\mathrm{ab}}$ & $1.06^{\mathrm{abc}}$ \\
\hline ICC4260 & $0^{\mathrm{a}}$ & $1^{\mathrm{ab}}$ & $0.67^{\mathrm{ab}}$ & $0.67^{\mathrm{ab}}$ & $0.67^{\mathrm{ab}}$ & 0 & $0.39^{\mathrm{a}}$ & $0.67^{\mathrm{a}}$ & $1.333^{\mathrm{ab}}$ & $1.33^{\mathrm{abc}}$ & $1.33^{\mathrm{abc}}$ & $2.33^{\mathrm{abc}}$ & $1.33^{\mathrm{b}}$ & $1.33^{\mathrm{abc}}$ \\
\hline ICC2767 & $1.33^{\mathrm{b}}$ & $1.67^{b}$ & $2^{\mathrm{b}}$ & $2^{\mathrm{bc}}$ & $3^{c}$ & 0 & $1.57^{\mathrm{c}}$ & $1^{\mathrm{ab}}$ & $2.67^{b}$ & $3.33^{\mathrm{c}}$ & $1.67^{\mathrm{abc}}$ & $4.67^{d}$ & $1.33^{b}$ & $2.433^{\mathrm{d}}$ \\
\hline ICC397375 & $0.67^{\mathrm{ab}}$ & $1.33^{\mathrm{ab}}$ & $0.67^{\mathrm{ab}}$ & $1.67^{\mathrm{abc}}$ & $0.67^{\mathrm{ab}}$ & 0 & $0.72^{\mathrm{ab}}$ & $1.33^{\mathrm{ab}}$ & $1.333^{\mathrm{ab}}$ & $1^{\mathrm{ab}}$ & $1.67^{\mathrm{abc}}$ & $1.33^{\mathrm{a}}$ & $1^{\mathrm{ab}}$ & $1.39^{\mathrm{bc}}$ \\
\hline ICC244624 & $0.33^{\mathrm{ab}}$ & $0.33^{\mathrm{ab}}$ & $0.67^{\mathrm{ab}}$ & $1^{\mathrm{ab}}$ & $1.33^{\mathrm{abc}}$ & 0 & $0.5^{\mathrm{ab}}$ & $2.33^{b}$ & $1.333^{\mathrm{ab}}$ & $2.33^{\mathrm{abc}}$ & $0.33^{\mathrm{ab}}$ & $2.33^{\mathrm{abc}}$ & $1^{\mathrm{ab}}$ & $1.61^{\mathrm{cd}}$ \\
\hline ICC3552 & $0^{\mathrm{a}}$ & $0^{\mathrm{a}}$ & $0^{\mathrm{a}}$ & $2.67^{c}$ & $0.67^{\mathrm{ab}}$ & 0 & $0.56^{\mathrm{ab}}$ & $0^{\mathrm{a}}$ & $0.67^{\mathrm{ab}}$ & $1.33^{\mathrm{abc}}$ & $2.33^{\mathrm{c}}$ & $3.33^{\text {abcd }}$ & $1^{\mathrm{ab}}$ & $1.45^{\mathrm{bc}}$ \\
\hline ICC6263 & $0.33^{\mathrm{ab}}$ & $1.33^{\mathrm{ab}}$ & $0.67^{\mathrm{ab}}$ & $1.33^{\mathrm{abc}}$ & $0.33^{\mathrm{a}}$ & 0 & $0.55^{\mathrm{ab}}$ & $1^{a b}$ & $1^{a b}$ & $2.33^{\mathrm{abc}}$ & $0.67^{\mathrm{abc}}$ & $1.67^{\mathrm{ab}}$ & $1^{\mathrm{ab}}$ & $1.18^{\mathrm{abc}}$ \\
\hline ICC372351 & $0^{\mathrm{a}}$ & $0^{\mathrm{a}}$ & $0^{\mathrm{a}}$ & $1^{\mathrm{ab}}$ & $0.33^{\mathrm{a}}$ & 0 & $0.28^{\mathrm{a}}$ & $0^{\mathrm{a}}$ & $0^{\mathrm{a}}$ & $0.67^{\mathrm{ab}}$ & $0^{\mathrm{a}}$ & $2^{\mathrm{abc}}$ & $0^{\mathrm{a}}$ & $0.5^{\mathrm{a}}$ \\
\hline ICC3404 & $0^{\mathrm{a}}$ & $0.33^{\mathrm{ab}}$ & $4.33^{c}$ & $1.67^{\mathrm{abc}}$ & $0.33^{\mathrm{a}}$ & 0 & $1.00^{\mathrm{abc}}$ & $1.33^{\mathrm{ab}}$ & $1.333^{\mathrm{ab}}$ & $1.33^{\mathrm{abc}}$ & $2^{\mathrm{bc}}$ & $2.67^{\mathrm{abcd}}$ & $0.67^{\mathrm{ab}}$ & $1.56^{\mathrm{bc}}$ \\
\hline ICC3089 & $0^{\mathrm{a}}$ & $0.33^{\mathrm{ab}}$ & $0^{\mathrm{a}}$ & $1^{\mathrm{ab}}$ & $1.33^{\mathrm{abc}}$ & 0 & $0.39^{\mathrm{a}}$ & $1^{\mathrm{ab}}$ & $1^{\mathrm{ab}}$ & $1.33^{\mathrm{abc}}$ & $0.67^{\mathrm{abc}}$ & $2.33^{\mathrm{abc}}$ & $0.33^{\mathrm{ab}}$ & $1.11^{\mathrm{abc}}$ \\
\hline ICC6938 & $0.33^{\mathrm{ab}}$ & $1.33^{\mathrm{ab}}$ & $0^{\mathrm{a}}$ & $0.67^{\mathrm{ab}}$ & $0.67^{\mathrm{ab}}$ & 0 & $0.39^{\mathrm{a}}$ & $1.33^{\mathrm{ab}}$ & $1.333^{\mathrm{ab}}$ & $2.33^{\mathrm{abc}}$ & $1.67^{\mathrm{abc}}$ & $2.33^{\mathrm{abc}}$ & $0.67^{\mathrm{ab}}$ & $1.61^{\mathrm{cd}}$ \\
\hline ICC3137 & $0.33^{\mathrm{ab}}$ & $1^{\mathrm{ab}}$ & $1.33^{\mathrm{ab}}$ & $1.33^{\mathrm{abc}}$ & $2.33^{\mathrm{bc}}$ & 0 & $0.89^{\mathrm{abc}}$ & $0.67^{\mathrm{a}}$ & $1^{\mathrm{ab}}$ & $2.33^{\mathrm{abc}}$ & $1.67^{\mathrm{abc}}$ & $4^{\text {cd }}$ & $1^{\mathrm{ab}}$ & $1.78^{\mathrm{cd}}$ \\
\hline GL25016 & $0^{\mathrm{a}}$ & $0^{\mathrm{a}}$ & $0.67^{\mathrm{ab}}$ & $1^{\mathrm{ab}}$ & $1.33^{\mathrm{abc}}$ & 0 & $0.55^{\mathrm{ab}}$ & $0.33^{\mathrm{a}}$ & $1.333^{\mathrm{ab}}$ & $0.67^{\mathrm{ab}}$ & $1^{\mathrm{abc}}$ & $3^{\mathrm{abcd}}$ & $0.67^{\mathrm{ab}}$ & $1.16^{\mathrm{abc}}$ \\
\hline ICCL86111 & $0.33^{\mathrm{ab}}$ & $0.33^{\mathrm{ab}}$ & $0.67^{\mathrm{ab}}$ & $0.33^{\mathrm{a}}$ & $0.67^{\mathrm{ab}}$ & 0 & $0.44^{\mathrm{ab}}$ & $0.33^{\mathrm{a}}$ & $0.67^{\mathrm{ab}}$ & $0.333^{\mathrm{a}}$ & $1.67^{\mathrm{abc}}$ & $1.67^{\mathrm{ab}}$ & $0.67^{\mathrm{ab}}$ & $0.72^{\mathrm{ab}}$ \\
\hline PG186 & $0.67^{\mathrm{ab}}$ & $1.33^{\mathrm{ab}}$ & $1.67^{\mathrm{ab}}$ & $1.67^{\mathrm{abc}}$ & $2^{a b c}$ & 0 & $1.16^{\mathrm{bc}}$ & $1^{\mathrm{ab}}$ & $1^{\mathrm{ab}}$ & $2.67^{b c}$ & $1.67^{\mathrm{abc}}$ & $3.67^{\mathrm{bcd}}$ & $1^{\mathrm{ab}}$ & $1.8^{\mathrm{cd}}$ \\
\hline SEm \pm & 0.23 & 0.27 & 0.35 & 0.30 & 0.36 & - & 0.14 & 0.30 & 0.46 & 0.41 & 0.33 & 0.38 & 0.24 & 0.16 \\
\hline CD@ $9 \%$ & 0.67 & 0.78 & 1.01 & 0.88 & 1.06 & - & 0.41 & 0.89 & 1.33 & 1.19 & 0.96 & 1.10 & 0.71 & 0.47 \\
\hline
\end{tabular}

S.W.- Standard week *Means in a column followed by the same letter(s) do not differ significantly at the 5\% level by Tukey's HSD test 
Table.2 Per cent pod damage due to $H$. armigera, yield and pest susceptibility rating of chickpea germplasm during 2017-18

\begin{tabular}{|c|c|c|c|c|c|}
\hline Sl.No & Germplasm & Per cent pod damage* & PSR & Category & Yield (kg/ha) \\
\hline $\mathbf{1}$ & ICC4484 & $8.18^{\text {bc }}$ & 3 & LS & 759.56 \\
\hline $\mathbf{2}$ & ICC4260 & $7.77^{\mathrm{b}}$ & 3 & LS & 912.72 \\
\hline $\mathbf{3}$ & ICC2767 & $15.99^{\mathrm{ef}}$ & 5 & LS & 652.89 \\
\hline $\mathbf{4}$ & ICC397375 & $10.18^{\mathrm{c}}$ & 4 & LS & 958.62 \\
\hline $\mathbf{5}$ & ICC244624 & $9.72^{\mathrm{bc}}$ & 3 & LS & 987.42 \\
\hline $\mathbf{6}$ & ICC3552 & $13.87^{\mathrm{de}}$ & 4 & LS & 821.81 \\
\hline $\mathbf{7}$ & ICC6263 & $16.96^{\mathrm{f}}$ & 5 & LS & 943.58 \\
\hline $\mathbf{8}$ & ICC372351 & $5.56^{\mathrm{a}}$ & 3 & LS & 1016.29 \\
\hline $\mathbf{9}$ & ICC3404 & $10.17^{\mathrm{c}}$ & 4 & LS & 1071.58 \\
\hline $\mathbf{1 0}$ & ICC3089 & $9.88^{\mathrm{bc}}$ & 3 & LS & 936.45 \\
\hline $\mathbf{1 1}$ & ICC6938 & $12.87^{\mathrm{d}}$ & 4 & LS & 971.46 \\
\hline $\mathbf{1 2}$ & ICC3137 & $20.17^{\mathrm{g}}$ & 6 & MS & 623.38 \\
\hline $\mathbf{1 3}$ & GL25016 & $10.29^{\mathrm{c}}$ & 4 & LS & 671.84 \\
\hline $\mathbf{1 4}$ & ICCL86111 & $8.56^{\mathrm{bc}}$ & 3 & LS & 897.64 \\
\hline $\mathbf{1 5}$ & PG186 & $19.82^{\mathrm{g}}$ & & & 831.45 \\
\hline SEm & & 0.418 & & & \\
\hline $\mathbf{C D}$ @ & & 1.210 & & & \\
\hline $\mathbf{5 \%}$ & & & & & \\
\hline
\end{tabular}

LS-least susceptible, MS-Moderately susceptible*Means in a column followed by the same letter(s) do not differ significantly at the $5 \%$ level by Tukey's HSD test

Mean number of eggs per five plants varied from the lowest of 0.28 eggs/5 plants on ICC 372351 to the highest of $1.57 \mathrm{eggs} / 5$ plants on ICC2767 as against 0.89 eggs/5 plants (ICC3137) to 1.16 eggs/5 plants (PG186) on check varieties. Above results were well supported by the findings of Maurya (2007), who observed that the number of eggs varied from 0.3 to 2.9 / 5 plants.

The similar results were also observed by Brar et al., (2015) who screened genotypes of chickpea against $H$. armigera and found that egg population varied from 2.30 to 15.74 per five plants. However, in the present study, the egg population varied from 0.28 to $1.57 / 5$ plants due to divergences in cultivars and change in the climatic conditions.

\section{Mean larval population per five plants}

The observations were recorded from $8^{\text {th }}$ S.W. to $13^{\text {th }} \mathrm{S} . \mathrm{W}$. (maturity of the crop). The perusal data clearly indicated that the population kept on increasing till the maturity of the crop. During the $8^{\text {th }} \mathrm{S}$.W. there was no larval population observed on ICC 3552 and ICC37235. The maximum number of larvae (2.33 larvae/5 plants) was recorded on ICC244624. There was non-significant difference observed between germplasm and check. Whereas during the $9^{\text {th }}$ S.W. the maximum number of larvae (2.67 larvae/5 plants) on germplasm ICC2767 and no larval population on germplasm ICC4484 and ICC372351 were observed as against 0.67 to 1.33 larvae/5 plants on check varieties. Nonsignificant differences were observed between germplasm and their checks. There was no 
significant difference in number of larvae per five plants amongst the germplasm and their check during $10^{\text {th }}$ S.W. However, it ranged from 0.67 larvae/5 plants on ICC372351 to 3.33 larvae $/ 5$ plants on ICC2767. During $11^{\text {th }}$ S.W. larval population varied from 0.00 (ICC372351) to 2.33 larvae/5 plants (ICC3552) as against 1.00 to 1.67 larvae/5 plants on checks. Larval population during $12^{\text {th }}$ S.W. varied non-significantly from the lowest of 1.33 larvae/5 plants on ICC397375 to the highest of 4.67 larvae/5 plants on ICC2767 as compared to 1.67 to 4 larvae/5 plants on check varieties. There was a nonsignificant difference in number of larvae per five plants between the germplasm and their check during $13^{\text {th }} \mathrm{S}$.W. however, it ranged from nil on ICC372351 to 1.33 larvae/5 plants on ICC2767 and ICC4260. As soon as the pods start to mature, the decline in the larval population was observed. When overall mean larval population of $H$. armigera was considered there were non-significant differences among the test germplasm. Mean number of larvae per five plants varied from the lowest of 0.5 larvae/5 plants on ICC 372351 to the highest of 2.43 larvae/5 plants on ICC2767 against 0.72 larvae/5 plants (ICCL 86111) to 1.8 larvae/5 (PG186) on check varieties. Above findings are in accordance with the studies conducted by Brar et al., (2015) who recorded a larval population varying from 0.27 to 13.28 per five plants.

\section{Per cent pod damage}

Low pod damage was recorded due to unfavorable climatic conditions to $H$. armigera during 2017-18. The per cent pod damage by $H$. armigera on the germplasm significantly varied from 5.56 per cent to 16.96 per cent (Table 2). The minimum per cent pod damage (5.56) was recorded in germplasm ICC372351 which differed significantly from others. The germplasm
ICC6263 (16.96) recorded maximum pod damage which was at par with ICC2767 (15.99) as against 19.82 per cent, 8.56 per cent, 10.29 per cent and 20.17 per cent in check varieties PG186, ICCL86111, GL25016 and ICC3137, respectively. These results are in agreement with the observations of Wakil et al., (2005) who recorded pod damage varying from 12.71 per cent to 38.83 per cent in chickpea by $H$. armigera. Chandile et al., (2017) also observed that the per cent pod damage varied from 4.94 to 10.14 per cent.

\section{Grain yield}

The grain yield of eleven test germplasm ranged from $652.89 \mathrm{~kg} / \mathrm{ha}$ to $1071.58 \mathrm{~kg} / \mathrm{ha}$ (Table 2). Significantly highest grain yield of $1071.58 \mathrm{~kg} / \mathrm{ha}$ was recorded in ICC 3404 . In other germplasm viz. ICC4484, ICC4260, ICC397375, ICC244624, ICC372351, ICC 3552, ICC6263, ICC3404, ICC3089 and ICC6938 recorded intermediate grain yield from $759.56 \mathrm{~kg} / \mathrm{ha}$ to $1016.29 \mathrm{~kg} / \mathrm{ha}$. Significantly lowest grain yield of 652.89 $\mathrm{kg} / \mathrm{ha}$ was recorded in ICC2767 which was at par with checks PG186 (831.45 kg/ha) and ICC3137 (623.38 kg/ha).

\section{References}

Brar, H.S., and Singh, R. 2015. Host plant resistance in chickpea against gram pod borer, Helicoverpa armigera (Hübner) under field and laboratory conditions. Journal of Food Legumes. 28(1): 69-72.

Chandile, P.G., Patange, N.R. and Sarnaik, B.C.S. 2017. Assessment of host plant resistance for management of gram pod borer, Helicoverpa armigera (Hubner). Journal of Entomology and Zoology Studies. 5(2): 1030-1033.

FAOSTAT 2017-18 (http://www.fao.org/faostat/en/). 
Kumar, H. and Kapur, A. 2003. Transgenic Bt crops as a component of Integrated Pest Management. In: Biotechnological Strategies in Agro-Processing. pp. 85104.

Lateef, S.S. and Sachan, J.N. 1990. Host plant resistance of Helicoverpa armigera (Hubner) in different agro-ecological context. In: Chickpea in Nineties Proceedings of the Second international Workshop on Chickpea, ICRISAT Center, Patancheru, Andhra Pradesh502 324, India. pp.181-189.

Maurya, R.P., Ujagir, R. and Ahmad, T. 2007. Evaluation of chickpea (Cicer arietinum L.) germplasm for the resistance to gram pod borer, Helicoverpa armigera Hübner
(Lepidoptera: Noctuidae). Journal of Entomological Research. 31(3): 181186.

Sarwar, M. 2013. Survey on screening resistance resources in some chickpea (Cicer arietinum L.) genotypes against gram pod borer Helicoverpa armigera (Hubner) (Lepidoptera: Noctuidae) pest. International Journal of Agriculture Science. 3: 455-458.

Wakil, W., Ashfaq, M., Hassan, M. and Javed, A. 2005. Evaluation of different chickpea (Cicer arietinum L.) genotypes against Helicoverpa armigera (Hub.) in Rawalpindi. Pakistan Entomologist. 27: 37-40.

\section{How to cite this article:}

Divija, S. D. and Meena Agnihotri. 2020. Evaluation of Chickpea (Cicer arietinum L.) Germplasm for the Resistance to Gram Pod Borer, Helicoverpa armigera (Hübner) in Tarai Region of Uttarakhand. Int.J.Curr.Microbiol.App.Sci. 9(09): 2210-2215. doi: https://doi.org/10.20546/ijcmas.2020.909.275 